\title{
PEMBINAAN GURU SEKOLAH MINGGU UNTUK MENGAJARKAN KONSEP KESELAMATAN PADA ANAK
}

\author{
Riniwati \\ Sekolah Tinggi Teologi Simpson \\ Email: riniwati5067@gmail.com
}

\begin{abstract}
This article discusses the formation of Sunday school teachers to teach children safety. The author uses a qualitative approach to analyze teacher needs, then the authors construct a pattern of coaching Sunday school teachers by elaborating sources of literature in accordance with the needs of teachers obtained from the needs analysis. The results of the needs analysis show there are three main needs needed by the teacher, namely aspects of knowledge about sin and salvation, aspects of personality where there are teachers who are still unsure of safety, and aspects of skills related to the ability to teach safety. The proposed pattern of coaching is to provide teaching about sin and salvation, the use of media for evangelism, mentoring or teacher supervision and evaluation.
\end{abstract}

Keywords: Sin, Salvation, Sunday School Teacher, Coaching.

\begin{abstract}
ABSTRAK: Artikel ini membahas tentang pembinaan guru sekolah minggu untuk mengajarkan keselamatan pada anak. Penulis menggunakan pendekatan kualitatif untuk menganalisis kebutuhan guru, kemudian penulis melakukan konstruksi pola pembinaan guru sekolah minggu dengan melakukan elaborasi sumber literatur sesuai dengan kebutuhan guru yang diperoleh dari hasil analisis kebutuhan. Hasil analisis kebutuhan menunjukkan ada tiga kebutuhan utama yang diperlukan guru yaitu aspek pengetahuan tentang dosa dan keselamatan, aspek kepribadian di mana ada guru yang masih ragu dengan keselamatan, dan aspek keterampilan berkaitan dengan kemampuan mengajarkan keselamatan. Pola pembinaan yang diusulkan adalah dengan memberikan pengajaran tentang dosa dan keselamatan, pemanfaatan media penginjilan, pendampingan atau supervisi guru dan evaluasi.
\end{abstract}

Kata kunci: Dosa, Keselamatan, Guru Sekolah Minggu, Pembinaan.

\section{PENDAHULUAN}

Pendidikan anak merupakan tugas penting dalam konteks pembinaan warga gereja. Anak-anak dalam gereja harus dididik dengan baik sebab pendidikan anak dapat diibaratkan sebagai proses penyiapan pemimpin gereja. Oleh sebab itu perlunya pelayanan anak Sekolah Minggu secara serius oleh guruguru Sekolah Minggu. Guru adalah komponen penting dalam pendidikan anak, sebab guru menjadi ujung tombak dalam menyampaikan firman Tuhan dalam pengajaran, kemudian guru juga menjadi pembimbing rohani anak-anak sehingga dapat mengalami pertumbuhan rohani. Diana (2019) mengungkapkan bahwa memasuki era revolusi industri 4.0 pendidikan terhadap anak menjadi semakin mendesak, sebab anak-anak diperhadapkan pada mudahnya akses berbagai informasi sehingga pendidikan perlu mengimbangi dengan menanamkan nilai-nilai yang posi- tif. Kemudian Wenas dan Darmawan (2017) menekankan bahwa Alkitab memandatkan pendidikan anak agar sejak anak-anak telah ditanamkan nilai-nilai spiritual yang akhirnya menjadi modal kehidupan anak.

Untuk mewujudkan pendidikan dalam gereja yang berkualitas, khususnya pada Sekolah Minggu maka dibutuhkan guru-guru yang terdidik, guruguru yang terlatih dan guru-guru yang memiliki beban untuk mengajar anak Sekolah Minggu (Darmawan, 2015). Dengan tersedianya guru-guru yang berkualitas maka akan membawa dampak positif dalam pelayanan Sekolah Minggu. Namun belum semua guru Sekolah Minggu melayani dengan baik. Hal ini dimungkinkan karenakan ada beberapa faktor yaitu: kurangnya pembekalan tentang pelayanan Sekolah Minggu, kurangnya minat dalam mengajar anakanak, guru itu sendiri belum mengerti hal yang mendasar yaitu tentang keselamatan di dalam Yesus se- 
cara pribadi. Permasalahan-permasalah seperti di atas menurut Kristiono dan Perdana (2019) dapat mempengaruhi pelayanan guru Sekolah Minggu. Padahal secara teoritis dan teologis, guru Kristen termasuk guru Sekolah Minggu berperan untuk mengajarkan keselamatan atau memberikan Injil kepada anak-anak (Juntak, 2019, p. 9). Itu sebabnya pembinaan perlu dilakukan dengan baik sehingga guru-guru dapat terus mengembangkan diri.

Keselamatan adalah salah satu doktrin penting dalam kekristenan. Tetapi keselamatan juga berkaitan dengan kehidupan seorang Kristen. Setiawan (2019) mengungkapkan bahwa pemahaman dan keyakinan tentang keselamatan memiliki kaitan dengan karakter seseorang, itu sebabnya hal ini penting bagi guru maupun murid. Hanya dalam mengajarkan keselamatan pada anak-anak, terdapat kesulitan sebagaimana yang diungkapkan oleh Tinggi (2010). Menurut Tinggi (2010) kesulitan guru dalam membimbing anak-anak percaya pada Yesus sebagai satu-satunya jalan keselamatan adalah ketika guru harus membimbing mereka satu persatu dan masih terbatasnya pemahaman mereka.

Hasil wawancara penulis dalam rangka konseling pribadi dengan salah satu guru Sekolah Minggu seputar keselamatan pribadi bahwa dia tidak dapat menjawab pertanyaan: kapan anda menerima Yesus sebagai Juruselamat pribadi. Padahal guru tersebut sudah mengajar di Sekolah Minggu. Hal ini mengagetkan penulis karena hal yang paling mendasar dari iman Kristen belum dialaminya. Dugaan penulis selanjutnya adalah kemungkinan bahwa ada guru yang lain juga belum menerima Yesus sebagai Juruselamat secara pribadi. Hal ini tampak dari beberapa guru yang masih ada kaitan dengan latar belakang okultisme yang belum dibereskan. Sejauh pengamatan penulis selama ini secara khusus di Gereja Kemah Injil Indonesia (GKII) Ungaran, guru yang mengajarkan kepada anak-anak Sekolah Minggu menekankan perbuatan baik misalnya harus taat kepada orang tua, dengan teman tidak berbohong, tidak mencuri dan sebagainya dengan tujuan agar anak Sekolah Minggu masuk sorga. Guru Sekolah Minggu ti- dak melayani Penginjilan Anak secara pribadi, karena memang guru itu sendiri tidak mengerti tentang keselamatan. Hal ini adalah masalah yang serius, yang memerlukan penanganan lebih lanjut. Hal ini menjadi keprihatinan dan sekaligus menjadi tantangan bagi para pendidik untuk memperhatikan masalah ini dan mencari solusi.

Dari latar belakang masalah di atas, menjadi alasan bagi penulis untuk meneliti tentang pembinaan guru sekolah minggu dalam mengajarkan tentang Yesus Juruselamat. Fenomena di atas sebenarnya tidak jauh berbeda dengan apa yang diamati oleh Owen. Owen (2005, p. 1) mengungkapkan bahwa terdapat fakta adanya orang-orang yang mengaku diri sebagai Orang Kristen tetapi kemudian meninggalkan imannya. Kekristenan yang dimaksud adalah benar-benar bahwa mereka pengikut Yesus yang sejati. Apa yang diungkapkan oleh Owen dapat terjadi karena orang tersebut belum memahami tentang keselamatan maupun belum dibimbing untuk mengerti keselamatan dalam Kristus. Tahap yang paling mendasar dalam kekristenan adalah keyakinan akan keselamatan di dalam Yesus.

Oleh sebab itu rumusan masalah dalam penelitian ini adalah bagaimana kebutuhan guru baru di Sekolah Minggu GKII Ungaran tentang keselamatan dan bagaimana usulan pola pembinaan terhadap guru baru? Tujuan dari penelitian adalah untuk menemukan bagaimana kebutuhan guru baru di Sekolah Minggu GKII Ungaran tentang keselamatan dan memaparkan usulan pola pembinaan terhadap guru baru.

\section{METODE}

Dalam penulisan ini, penulis menggunakan penelitian kualitatif dengan pendekatan analisis pustaka. Pendekatan ini menurut Purwanto dapat digunakan untuk meneliti kondisi yang berkaitan dengan pembinaan warga jemaat (Purwanto, 2016). Penulis memilih penelitian kualitatif karena dalam penelitian ini penulis membutuhkan informasi yang mendalam tentang kebutuhan pembinaan guru baru di Sekolah Minggu GKII Ungaran. Zaluchu (2020) dan Wijaya (2017) mengungkapkan bahwa penelitian kualitatif 
dapat dipilih untuk memperoleh data yang dibutuhkan dalam penelitian ini.

Penelitian ini dilakukan pada guru-guru baru di Sekolah Minggu GKII Ungaran, terutama pada guru-guru yang baru mulai terlibat mengajar di Sekolah Minggu. Pengumpulan data wawancara dan observasi penulis lakukan pada rentang April hingga Juni 2019. Penulis melakukan observasi dan wawancara tidak terstruktur pada guru-guru baru di Sekolah Minggu GKII Ungaran untuk memperoleh analisis kebutuhan guru, sehingga dapat ditindaklanjuti dengan rancangan pola pembinaan guru. Penulis melakukan pembandingan hasil observasi dan wawancara tidak terstruktur sehingga dapat dihasilkan data yang objektif. Hasil observasi dan wawancara kemudian penulis tindaklanjuti dengan membuat gagasan pola pembinaan guru Sekolah Minggu. Gagasan yang dihasilkan dari proses pengumpulan data dan konstruksi teoritis penulis ajukan bagi pembinaan guru di GKII Ungaran. Gagasan yang penulis usul- kan kemudian dielaborasi dengan sumber-sumber pustaka yang relevan sehingga secara teoritis penelitian ini sejalan dengan beberapa teori.

\section{HASIL DAN PEMBAHASAN}

\section{Analisis Kebutuhan Guru}

Tahap awal dalam pengembangan pembinan guru adalah melakukan analisis kebutuhan. Tahapan ini dilakukan dengan beberapa cara yaitu wawancara, pembagian angket, grup diskusi, maupun dokumentasi. Sasaran dari analisis kebutuhan menurut Wiyono, Kusmintardjo, dan Supriyanto (2014) adalah untuk mengetahui kemampuan apa yang dibutuhkan oleh guru untuk kepentingan peningkatan mutu pembelajarannya. Dari hasil analisis terhadap data yang dikumpulkan hasil wawancara tidak terstruktur dan observasi maka ada beberapa kebutuhan guru baru Sekolah Minggu di GKII Ungaran:

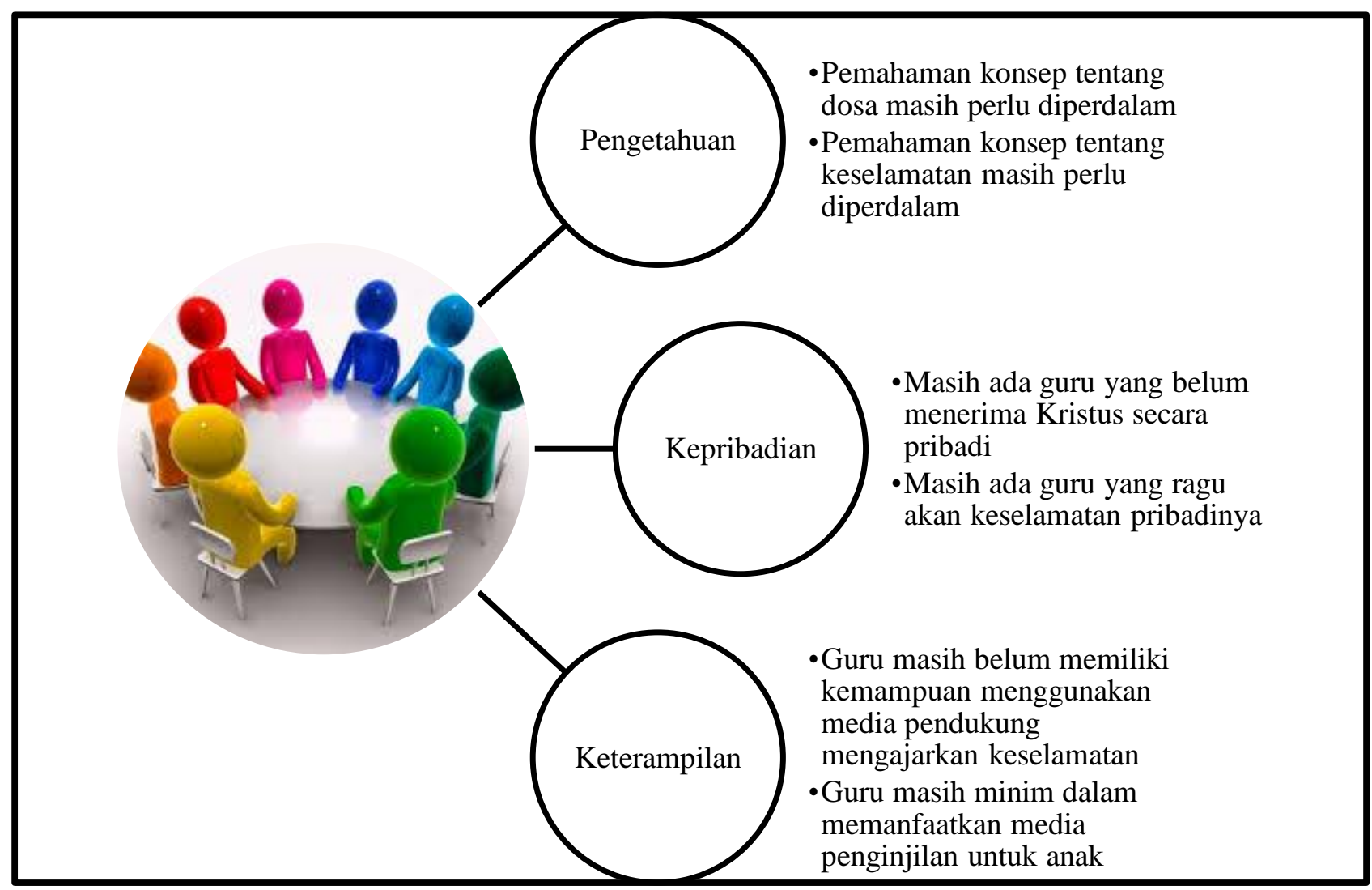

Gambar 1. Hasil Analisis Kebutuhan 
Dari gambar di atas tampak ada tiga bagian utama dari kebutuhan guru Sekolah Minggu baru di GKII Ungaran. Kebutuhan-kebutuhan tersebut berkaitan dengan masalah pemahaman tentang keselamatan dan kemampuan untuk mengajarkan tentang keselamatan. Dari data yang dikumpulkan juga menunjukkan bahwa ada guru yang masih belum mengenal Kristus secara pribadi. Karena tugas pendidikan bagi anak begitu penting maka guru yang melayani anak juga perlu dibina. Secara teoritis, seorang guru Sekolah Minggu haruslah seorang yang telah mengenal Kristus sebab tugas mereka adalah untuk membimbing anak-anak mengenal Kristus secara pribadi (Darmawan, 2015; Tong, 2015).

\section{Pola Pembinaan Guru}

Ada beberapa hal yang harus dilakukan dalam pembinaan guru Sekolah Minggu agar mereka dapat mengajarkan tentang keselamatan.

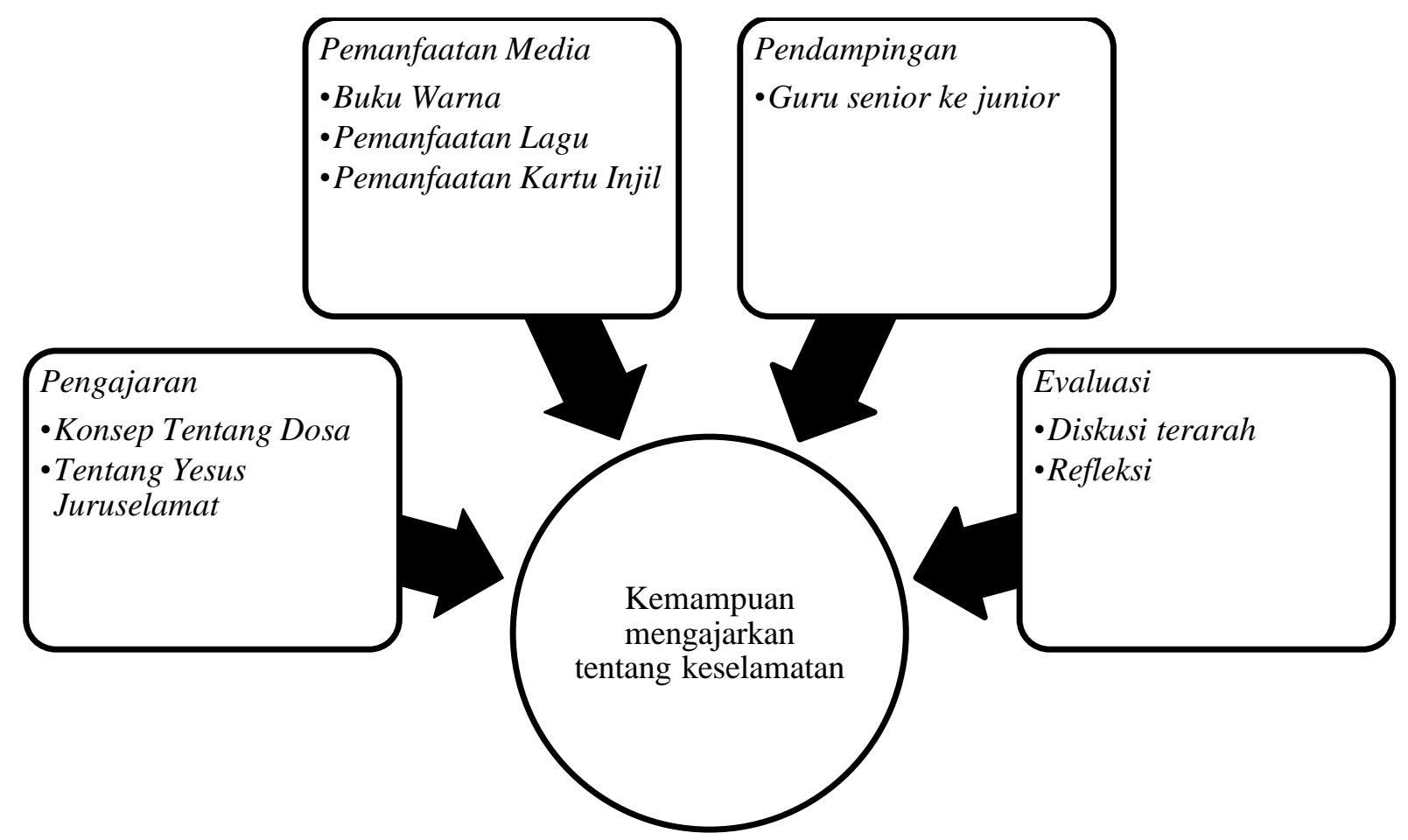

Gambar 2. Pembinaan Guru Baru Sekolah Minggu

\section{Pengajaran}

Alkitab dalam Matius 28: 18-20 ditekankan tugas untuk menjadikan segala bangsa murid Kristus. Darmawan (2019) menjelaskan bahwa tugas gereja adalah menjadikan setiap orang murid Kristus. Penjelasan tersebut mengacu pada kajiannya terhadap Matius 28:19-20. Teks Matius 28:19-20 jelas menunjukkan bahwa kehendak Allah untuk dilaksanakan pada masa sekarang ini adalah agar seluruh bangsa menjadi murid Tuhan Yesus (Febriana, 2017). Dalam hal ini secara khusus guru-guru Sekolah Minggu harus menjadikan muridnya sebagai murid Kristus. Oleh sebab itu, jika guru baru belum memahami secara mendalam tentang keselamatan maka guru perlu dibina agar dapat melaksanakan amanat agung dalam Matius 28:19-20. 
tentang dosa dan mampu menyusun sebuah struktur konsep sederhana yang dapat dipahami oleh anak. Tinggi (2010) mengungkapkan bahwa dalam menyampaikan Injil pada anak-anak, guru harus menstrukturkan secara sederhana konsep dosa. Konsep yang harus distrukturkan secara sederhana adalah pengertian dosa, bentuk-bentuk dosa, dan dampak dari dosa. Masalah dosa yang tidak dapat diselesaikan sendiri oleh manusia, sehingga Yesus menjalani hukuman untuk menyelesaikan masalah tersebut (Janes, 2018). Karena dengan memahami konsep tersebut anak-anak dapat diarahkan pada karya penyelamatan Yesus.

Dalam membina guru-guru Sekolah Minggu, konsep ini harus ditanamkan dengan baik sehingga guru sekolah minggu dapat mengajarkannya dengan baik. Guru kemudian dibina untuk mampu menyusun secara sederhana materi pembelajaran tentang dosa dan keselamatan agar dapat dipahami oleh anak-anak sesuai dengan perkembangan usianya.

Selain itu, guru juga dapat diajarkan menggunakan pendekatan EE Kids. Dalam laman EE Internasional ('Kids' EE', n.d.) dijelaskan bahwa pendekatan ini berfungsi untuk meletakkan dasar iman Kristen bagi pertumbuhan rohani anak-anak dan menyadarkan kasih karunia Allah bagi manusia yang berdosa. Dengan demikian, guru dapat dibina untuk memahami konsep dosa secara sederhana dan menggunakan pendekatan ini dalam mengajarkan konsep tentang dosa.

\section{Mengajarkan Tentang Yesus Juruselamat}

Sujoko (2017) maupun Setiawani dan Tong (2008) menjelaskan bahwa dalam pelayanan anak, peran guru Kristen adalah untuk mengenalkan Yesus sebagai Juruselamat. Oleh sebab itu, tahap awalnya adalah guru harus diperlengkapi terlebih dahulu pengetahuan dan pengalaman tentang keselamatan di dalam Kristus. Sebagaimana masalah yang tergambar dalam analisis kebutuhan di atas, maka pembinaan guru baru Sekolah Minggu dimulai dari tahap yang paling mendasar yaitu mengajarkan tentang Yesus adalah Juruselamat. Dengan demikian guru
Sekolah Minggu dapat memberikan pengajaran yang benar bagi anak-anak, sehingga akhirnya anak-anak mengalami pertumbuhan rohani dan berkembang dalam pengenalan akan Allah, sehingga memiliki kehidupan yang layak di hadapan Tuhan (Kol. 1:10). Tidakan pembinaan yang mengajarkan tentang keselamatan sejalan dengan tujuan pembinaan bahwa konsep Yesus Kristus adalah Juruselamat merupakan konsep yang mendasar dalam kekristenan. Selain itu, bagi GKII, konsep Yesus Juruselamat tertanam dalam teologi kemah Injil maupun simbol gereja (Simpson, 2012). Oleh sebab itu, tahap kedua dalam pembinaan adalah membina guru untuk memahami konsep Yesus Juruselamat.

Dalam kekristenan, keselamatan adalah hal yang utama dari hidup manusia. Hal ini juga dicari oleh agama-agama lain. Mereka berbuat amal, berbuat baik, beraskese dan sebagainya untuk tujuan keselamatan. Ada orang kaya yang sudah merasa nyaman hidupnya, atau ada orang yang sangat pintar, terkenal dikagumi banyak orang tetapi belum tentu mereka diselamatkan, artinya itu semua tidak ada gunanya di luar Kritsus. Di luar Kristus yang didapatkan adalah kematian kekal. Matius 16:26 menjelaskan, “Apa gunanya seorang memperoleh seluruh dunia tetapi kehilangan nyawanya? Dan apakah yang dapat diberikannya sebagai ganti nyawanya? Dari ayat ini jelas bahwa yang terpenting adalah kepastian keselamatan, artinya memiliki jaminan bahwa orang memiliki hidup yang kekal. Hal ini penting untuk dimiliki oleh guru-guru Sekolah Minggu. Mereka Kristen, mengajarkan Firman Tuhan kepada anak-anak Sekolah Minggu, tetapi ternyata dirinya sendiri belum menjadi miliki Tuhan. Itu adalah hal sangat disayangkan. Oleh sebab itu para pendidik, atau para gembala memiliki kewajiban untuk melayani para guru sekolah Minggu dengan penginjilan pribadi. Jadi menjadi guru sekolah Minggu tidak hanya sekedar suka rela melayani tanpa gaji, tetapi lebih dari itu, mereka adalah orangorang yang sudah memiliki keyakinan keselamatan atau sudah lahir baru. Ketiga, Mengajarkan pertumbuhan iman yang benar. Gereja yang bertumbuh 
adalah gereja yang menjalankan pembinaan kepada warga jemaatnya, termasuk mempersipakan guru Sekolah Minggu menjadi guru yang siap melayani dengan baik, cakap dan memiliki integritas. Abraham Tefbana mengatakan bahwa adalah mustahil gereja dapat bertumbuh secara seimbang antara kualitas dan kuantitas tanpa adanya pengajaran Firman Tuhan yang alkitabiah kepada jemaatnya. Jadi guruguru Sekolah Minggu harus mendapatkan pengajaran yang benar dari pemimpn jemaat dan membina mereka baik dari segi pengajaran Firman Tuhan maupun dari segi teknik, strategi mengajar dengan baik, agar apa yang diajarkan mencapai tujuan (Tefbana, 2016).

\section{Pemanfaatan Media}

Langkah berikutnya adalah memperlengkapi guru Sekolah Minggu dalam rangka tugas mengajarnya baik itu dari strategi mengajarnya, keterampilan mengajar, penginjilan Anak dan sebagainya. Pemanfaatan media pembelajaran merupakan bagian dari keterampilan mengajar. Karena kondisi guru Sekolah Minggu yang penulis observasi dan wawancara maka perlu pembinaan untuk dapat memanfaatkan media pembelajaran yang tepat. Beberapa media untuk mengajarkan tentang keselamatan pada anak adalah buku warna tanpa kata maupun gambar hati manusia. Hannas dan Rinawaty (2019) menjelaskan bahwa buku tanpa kata adalah buku yang tidak berisikan kata-kata dan hanya berisi warna yaitu warna emas, hitam, merah, putih, dan hijau. Sementara gambar hati manusia adalah alat peraga penginjilan yang berisi gambar tentang kehidupan manusia yang berdosa dan akibatnya serta cara Allah menyelesaikannya.

Selain media tersebut, guru juga dapat menggunakan media lagu. Halim (2018, p. 193) mengungkapkan bahwa lagu adalah media yang efektif untuk mengajarkan tentang Yesus Juruselamat. Halim menyarankan agar guru dapat memilih lagu yang menceritakan tentang Yesus. Dengan demikian, guru kemudian dapat mengarahkan cerita pada konsep keselamatan dalam Yesus.
Media kartu Injil seperti yang dikembangkan oleh EE Internasional dapat digunakan juga dalam membantu mengenalkan Yesus Juruselamat. Selain itu, Halim (2018, p. 721) mencontohkan kartu-kartu disertai gambaran jelas, kemudian dipotongpotong sehingga menarik perhatian. Penggunaan media kartu dapat disajikan dengan pembelajaran yang melibatkan aktivitas seperti permainan atau juga dapat menggunakan pembelajaran picture and picture. Penelitian Darmawan dan Kristanti (2020) menunjukkan bahwa picture and picture dapat digunakan dalam pembelajaran di Sekolah Minggu. Pembelajaran ini juga membantu agar murid dapat menyimak penjelasan tentang keselamatan.

Penggunaan media tersebut membutuhkan keterampilan yang baik. Oleh sebab itu, untuk menjawab kebutuhan dalam pembinaan guru Sekolah Minggu, guru-guru perlu dibina menggunakan media-media tersebut. Pembinaan dapat dilakukan dengan cara pemberian teori dan simulasi, kemudian dilanjutkan dengan melakukan praktik atau bahkan pengembangan dari apa yang telah disajikan.

\section{Pendampingan}

Pola supervisi tampaknya perlu dilakukan sebagai upaya pembinaan guru Sekolah Minggu. Pendampingan ini dilakukan dengan menunjuk guru yang lebih senior untuk melakukan supervisi terhadap guru yang junior. Menurut Bermawi \& Fauziah (2015, p. 16) menjelaskan bahwa supervisi merupakan cara yang efektif untuk meningkatkan profesionalitas guru. Demikian pula diungkapkan oleh Darmawan (2017) maupun Yusak dan Darmawan (2017) bahwa supervisi merupakan salah satu faktor dalam peningkatan profesionalitas guru. Oleh sebab itu, dalam upaya untuk meningkatkan mutu guru Sekolah Minggu dalam mengajarkan tentang konsep keselamatan di dalam Kristus maka perlu pendampingan atau supervisi dari guru senior.

Pendampingan dalam hal ini juga bertujuan agar guru mampu melakukan tugasnya untuk memberikan bimbingan pada anak-anak sekolah minggu. Dalam mengajarkan keselamatan, guru dapat mela- 
kukan bimbingan pribadi pada anak sebab ada perintah dalam Alkitab yang mengatakan,"...He said to him feed My lambs." (John. 21:15). Artinya ayat tersebut bahwa Tuhan memerintahkan untuk memelihara/memberi makan anak-anak-Nya, (domba yang masih kecil). Dalam konteks ayat tersebut, Tuhan memerintahkan untuk menangani pelayanan secara khusus untuk anak-anak, agar nantinya akan menjadi jemaat yang dewasa dan tidak terhilang di kemudian hari. Dalam Yohanes 21:15-17 terjemahan bahasa Indonesia, Tuhan mengulangi kalimat yang sama yaitu "Gembalakanlah domba-domba-Ku". Tetapi dalam bahasa Inggris, ayat yang ke 15 Tuhan memakai kata 'lambs' artinya itu adalah jamak, anakanak domba. Tetapi pada ayat yang ke 16, dalam Alkitab bahasa Inggris, Tuhan Yesus mengatakan, "Tend My Sheep," yang artinya rawatlah domba-Ku, artinya bukan anak-anak domba lagi seperti ayat yang 15 , tetapi domba yang sudah dewasa, dan tidak menunjukkan jamak, tetapi satu. Satu domba dewasa. Pada ayat yang ke 17 Tuhan mengatakan, "Feed My Sheep" yang artinya berilah makan domba-Ku. Artinya memberikan pengajaran dan pelayanan secara perorangan atau secara pribadi, satu persatu. Jika domba itu hilang, domba itu harus dicari. Artinya melayani jemaat itu haruslah secara serius dan pribadi, secara menyeluruh atas dasar mengasihi Tuhan dan kebenaran Firman Tuhan.

\section{Evaluasi}

Evaluasi adalah komponen penting dalam pembinaan guru. Proses evaluasi dapat dilakukan dengan menggunakan berbagai pendekatan seperti context, input, proces dan product atau disebut sebagai model evaluasi CIPP (Anamara, 2014). Pendekatan tersebut dapat melihat efektivitas dan efisiensi kegiatan maupun ketercapaian kegiatan (Sarah, 2016). Tetapi dalam konteks pendidikan, evaluasi dapat menggunakan pendekatan lesson study. Model evaluasi ini dapat digunakan dalam pembinaan ini dengan melaksanakan diskusi terarah dan refleksi (Pahrudin, Martono, \& Murtini, 2016). Evaluasi melalui diskusi terarah dilakukan bersama guru-guru lain, kemudian melakukan penyampaian pendapat terhadap apa yang telah dirancang dan dilaksanakan dalam pembelajaran oleh guru baru. Dalam bagian ini guru-guru senior dapat memberikan masukanmasukan yang berkaitan dengan materi tentang keselamatan dan aspek teknis dalam pembelajaran. Kemudian refleksi dapat dilakukan dengan diskusi antara guru baru dengan guru pendamping. Erikasari (2019) mengungkapkan bahwa dengan dilaksanakan refleksi maka guru dapat didorong menjadi lebih peka terhadap hal-hal yang perlu ditingkatkan dalam melaksanakan pembelajaran. Hal-hal yang perlu ditanyakan dalam refleksi adalah 1) Bagaiamana penguasaan materi tentang keselamatan? 2) Bagaiamana pengelolaan suasana kelas? 3) Hal-hal apa yang perlu ditingkatkan, diminimalkan, dan dipertahankan? Guru juga dapat menambah beberapa pertanyaan sebagai bagian dari refleksi sehingga dapat terjadi peningkatan mutu pembelajaran oleh guru Sekolah Minggu baru di GKII Ungaran.

\section{KESIMPULAN}

Dari hasil analisis kebutuhan ada tiga kebutuhan utama yang perlu ditingkatkan pada guru baru yaitu kebutuhan pengetahuan, dimana ada masalah pemahaman guru tentang konsep dosa dan keselamatan. Kebutuhan kedua adalah kepribadian yaitu adanya guru yang masih belum menerima dan ragu tentang keselamatan pribadinya. Kebutuhan ketiga adalah keterampilan yaitu adanya masalah dalam kemampuan untuk menggunakan media pendukung mengajarkan keselamatan dan masih minim dalam memanfaatkan media penginjilan untuk anak.

Pola pembinaan yang penulis usulkan diharapkan dapat meningkatkan kemampuan mengajarkan tentang keselamatan. Ada empat bagian dalam pembinaan guru baru bagi Sekolah Minggu yaitu: 1) Pengajaran tentang konsep dosa dan keselamatan karena hal ini berkaitan dengan kebutuhan pertama dan kedua; 2) Pelatihan pemanfaatan media seperti buku warna, pemanfaatan lagu, maupun pemanfaatan kartu Injil; 3) Pendampingan yang dilakukan oleh guru senior ke junior agar dapat memberikan bimbingan 
pribadi dan terarah yang akhirnya bermuara pada peningkatan kemampuan mengajar; 4) Evaluasi yang

\section{DAFTAR RUJUKAN}

Anamara, M. G. V. (2014). Evaluasi Program Implementasi Standar PAUD. Jurnal Pendidikan Usia Dini, 8(2), 301-314.

Bermawi, Y., \& Fauziah, T. (2015). Supervisi Kepala Sekolah Terhadap Kompetensi Profesional Guru. Jurnal Pesona Dasar, 1(4), 16 24.

Darmawan, I P. Ayub. (2015). Dasar-dasar Mengajar Sekolah Minggu. Ungaran: Sekolah Tinggi Teologi Simpson.

Darmawan, I. Putu Ayub. (2017). Faktor Yang Mempengaruhi Profesionalitas Guru. Prosiding Seminar Nasional Pendidikan Agama Kristen dan call for papers, 25-31. Retrieved from http://semnas.sttsimpson. ac.id/index.php/SNPK/article/view/19

Darmawan, I. Putu Ayub. (2019). Jadikanlah Murid: Tugas Pemuridan Gereja Menurut Matius 28:18-20. Evangelikal: Jurnal Teologi Injili dan Pembinaan Warga Jemaat, 3(2), 144153.

Darmawan, I. Putu Ayub, \& Kristanti, D. (2020). Penerapan Model Pembelajaran Picture and Picture dalam Pembelajaran di Sekolah Minggu. REGULA FIDEI: Jurnal Pendidikan Agama Kristen, 5(1), 1-12. https://doi.org/10.33541/regula fidei.v5i1.38

Diana, R. (2019). Prinsip Teologi Kristen Pendidikan Orang tua terhadap Anak di Era Revolusi Industri 4.0. BIA': Jurnal Teologi Dan Pendidikan Kristen Kontekstual, 2(1), 27 39. https://doi.org/10.34307/b.v2i1.79

Erikasari, E. (2019). Peranan refleksi guru dalam upaya meningkatkan manajemen kelas (Bachelor, Universitas Pelita Harapan). Retrieved from http://repository.uph.edu/ $5859 /$ dilaksanakan melalui diskusi terarah dan refleksi.

Febriana, M. (2017). Puritan Dan Pemuridan: Mind, Heart And Life In The Making. Jurnal Theologia Aletheia, 19(12), 24.

Halim, M. (2018). Model-Model Penginjilan Yesus: Suatu Penerapan Masa Kini. Malang: Yayasan Penerbit Gandum Mas.

Hannas, H., \& Rinawaty, R. (2019). Menerapkan Model Penginjilan pada Masa Kini. KURIOS (Jurnal Teologi Dan Pendidikan Agama Kristen), 5(2), 175-189. https://doi.org/10.30995/kur.v5i2.118

Janes, J. (2018). Pemahaman Doktrin Soteriologi Terhadap Kegiatan Memberitakan Injil. PRUDENTIA: Jurnal Teologi dan Pendidikan Kristiani, 1(1), 74-93.

Juntak, J. N. S. (2019). Pengaruh Pemahaman Panggilan Guru Kristen terhadap Pemberitaan Injil. EPIGRAPHE: Jurnal Teologi Dan Pelayanan Kristiani, 3(1), 9-20. https://doi.org/10.33991/epigraphe.v3i1.44

Kids' EE. (n.d.). Retrieved 24 June 2020, from Evangelism Explosion website: https://evangelismexplosion.org/ministries/k ids-ee/

Kristiono, T., \& Perdana, D. P. (2019). Hambatan Guru dan Pelayanan Sekolah Minggu di Gereja Kristen Jawa Jebres Surakarta. JURNAL TEOLOGI GRACIA DEO, 1(2), 90-100.

Owen, J. (2005). Christian Are Forever. Surabaya: Momentum.

Pahrudin, P., Martono, T., \& Murtini, W. (2016). The Effect of Pedagogic Competency, Personality, Professional and Social Competency Teacher to Study Achievement of Economic Lesson in State Senior High School of East Lombok District Academic Year 2015/2016. Proceeding of the International Conference on Teacher Training and Education, 2(1), 332-345. 
Purwanto, H. (2016). Manfaat Penelitian Untuk Perkembangan Gereja. Prosiding Seminar Nasional Pendidikan Agama Kristen STT Simpson Tahun 2016 Tema: Strategi Pembinaan Jemaat Untuk Meningkatkan Kehidupan Jemaat. Presented at the Seminar Nasional Pendidikan Agama Kristen \& call for papers, Ungaran.

Sarah, Y. Y. (2016). Evaluasi Kebijakan Relokasi Pengungsi Erupsi Gunung Sinabung Di Desa Siosar Kecamatan Merek Kabupaten Karo Sumatera Utara (Skripsi, Universitas Negeri Lampung). Retrieved from http://digilib.unila.ac.id/24980/

Setiawan, D. E. (2019). Kelahiran Baru Di Dalam Kristus Sebagai Titik Awal Pendidikan Karakter Unggul. Evangelikal: Jurnal Teologi Injili dan Pembinaan Warga Jemaat, 3(2), 154-161.

Setiawani, M., \& Tong, S. (2008). Seni Membentuk Karakter Kristen. Jakarta: LRII.

Simpson, A. B. (2012). Injil Empat Berganda. Bandung: Kalam Hidup.

Sujoko, E. (2017). Model Pengembangan Pelayanan Anak. In Melaksanakan Amanat Agung di Abad 21 (pp. 47-64). Ungaran: Sekolah Tinggi Teologi Simpson.

Tefbana, A. (2016). Sumbangsih Pendidikan Agama Kristen Bagi Pertumbuhan Gereja. Jurnal Luxnos, 1(1), 20-59.

Tinggi, R. (2010). Mengajarkan Injil Kepada Anak Usia Empat Sampai Lima Tahun. Jurnal Amanat Agung, 6(1), 71-86.
Tong, S. (2015). Membesarkan Anak Dalam Tuhan. Surabaya: Momentum.

Wenas, M. L., \& Darmawan, I. P. A. (2017). Signifikansi Pendidikan Anak Dalam Perspektif Alkitab. Evangelikal: Jurnal Teologi Injili dan Pembinaan Warga Jemaat, 1(2), 118-128.

Wijaya, H. (2017). Metodologi Penelitian Pendidikan Teologi. Makassar: Sekolah Tinggi Theologia Jaffray.

Wiyono, B. B., Kusmintardjo, K., \& Supriyanto, A. (2014). Grand Design Model Pembinaan Profesional Guru Berbasis Determinan Kinerja Guru. Jurnal Ilmu Pendidikan, 20(2), 165-175. https://doi.org/10.17977/ jip.v20i2.4613

Yusak, L., \& Darmawan, I. P. A. (2017). Supervisi Kepala Sekolah Di SD Negeri Kalongan 02, Desa Kalongan, Kecamatan Ungaran Timur. Prosiding Seminar Nasional Pendidikan Agama Kristen dan call for papers. Presented at the Seminar Nasional Pendidikan Agama Kristen dan call for papers, Ungaran. Retrieved from http://semnas.sttsimpson. ac.id/index.php/SNPK/article/view/23

Zaluchu, S. E. (2020). Strategi Penelitian Kualitatif dan Kuantitatif Di Dalam Penelitian Agama. Evangelikal: Jurnal Teologi Injili dan Pembinaan Warga Jemaat, 4(1), 28-38. https://doi.org/10.46445/ejti.v4i1.167 